\title{
The Exploration and Research on Bilingual education of Computer Discipline
}

\author{
Feng Xingle, Sun Zhaoyun, Cheng yan, Bao Yupu \\ School of Information Engineering, Chang'an University, Xi'an, Shaanxi, China
}

\begin{abstract}
In view of the present problems of bilingual education in domestic universities, combined with the author's practice of bilingual education of computer course in recent years, this paper analyzes the common existing problems and the causes from the aspect of teaching target, curriculum planning, teacher cultivating, teaching material construction, teaching methods, assessment system and management mechanism, etc. Moreover, it puts forward improving countermeasures and suggestions by combining with the specific practice of bilingual education for computer discipline.
\end{abstract}

Index Terms: Bilingual education; Computer Discipline; Teaching methods

(C) 2012 Published by MECS Publisher. Selection and/or peer review under responsibility of the International Conference on E-Business System and Education Technology

\section{1. "THE STATUS OF THE BILINGUAL EDUCATION IN DOMESTIC AND ABROAD"}

Internationally in many countries, bilingual education has a long history and accumulates massive success experience. For example, Canada who has many French descent of Canadian executes soaking type of bilingual education. These students keep soaking in the environment of two languages since in primary school; but in Singapore where Chinese ethnic occupy mostly executes with the non-parallel bilingual education which makes English as the dominant language. They implement to teach students according to their aptitude of English and mother tongue.

In China, at present, the bilingual education is still in the exploratory stage since it starts lately [1]. On the one hand, most of the teachers in domestic key universities have a doctor's or master's degree, and they have strong English reading ability. And in recent years among colleges and universities, proportion of returned students from abroad is also gradually increasing. It has laid a good foundation on the 'teachers' parts' for developing bilingual education. On the other hand, as for the influence of traditional education idea and limitations of policy environment, currently it has many problems to be solved in ongoing bilingual education in the aspect of teachers, teaching materials, teaching methods, and the evaluation system.

Although the Ministry of Education in teaching evaluation has specific rules in related files on the proportion of bilingual courses, we still lack a set of reasonable and feasible evaluation system on the quality of bilingual education. Because of the idea of value or "false value" on the concept, under the "great prosperity" of thriving

* Corresponding author.

E-mail address: xlfeng@chd.edu.cn 
bilingual education in our country, it has appeared a number of "pseudo bilingual" who are included in a group just to fill in a vacancy [4]. Thanks to the lack of scientific planning and selection to open bilingual curriculum, and lack of the selection and training mechanism to bilingual teachers, as a result the teaching cannot attain the desired effect. Students and society all have low satisfaction of bilingual education. Most students consider that the effect of bilingual education is not significant, and even some students think that they can't master neither English nor professional knowledge.

As the chief lecturing teacher, the author's lecture named "Delphi Advanced Programming Techniques" in Chang' an University has been titled as the national bilingual education demonstration course construction project in 2008. This paper focus on the problems of domestic colleges and universities in teaching concept, teaching methods, evaluation system, teaching staff and materials and other issues, with the combination of author's practice for being major teacher in bilingual education for three years, introduce some bilingual education ideas and methods to achieve the goal of attracting valuable opinions.

\section{Elements Model of Bilingual education}

From the mode of teaching in the propagation process, main factors which affect the quality of college bilingual education include [3]: teachers, teaching objectives, teaching content, teaching media, teaching objects and teaching environment etc. The relationship between them is shown in figure1:

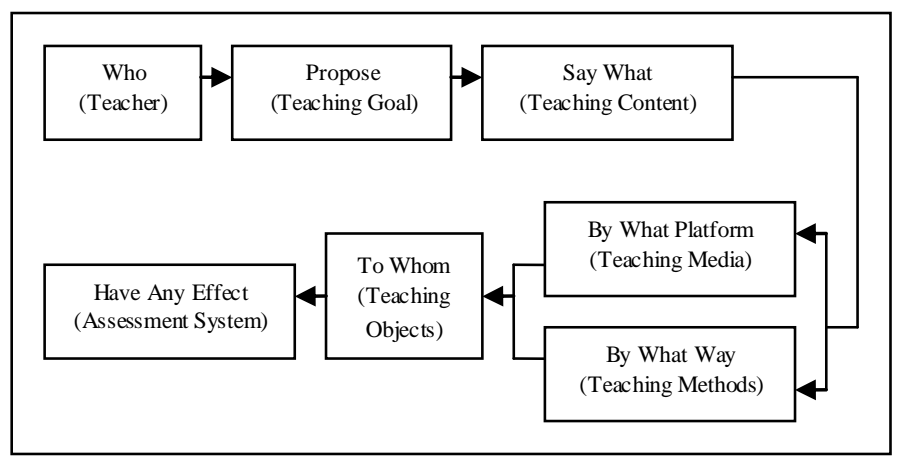

Fig.1 Mode in the Propagation Process of Teaching

Teachers are the subject of teaching activities, and the senders of teaching content, they are playing a leading role in the teaching process. For bilingual teachers, they should not only have high academic standards, but also have superb ability to use the foreign languages.

Teaching goal is either the starting point or the ending point of teaching. To guarantee the quality of the bilingual education in universities, we must require the society, schools, teachers and students have consensus on teaching goals and especially on the relationship between discipline knowledge and foreign language learning. And therefore to make out formulation and implementation of all recognized scientific and reasonable policies and measures.

Teaching content means the organized and lectured knowledge according to teaching aims. For bilingual education, it should be based on the principle from easy to difficult, gradual progress and teaching students according to their aptitude. We should not only choose the appropriate courses of bilingual education according to the current situation of teachers and students, namely course planning; at the same time we should base on students' basic and bilingual education characteristics to make a reasonable arrangement of teaching content, in order to ensure the teaching efficiency and quality.

Teaching media refers to traditional media (such as teaching materials, blackboard, wall charts), electronic media (such as projection, video), information media (computer, network), etc. From the perspective of bilingual education, it requires the teaching material choice to be scientific and rational, difficulty appropriately, and it makes full use of multi media to spread teaching information in multi-angle, and makes it easier for 
students to understand the content, realizes the organic combination of modern teaching media and the traditional one.

Teaching methods include teaching mode, practice link and examining, it is an important link of affecting the teaching quality.

Teaching objects. However, most students are the teaching objects, and the bearers in teaching activities, students are not passively accepted of granted knowledge from teachers, it's an initiative cognitive process which is based on the learners' own existing knowledge and learning motivation. Therefore, bilingual education quality of colleges and universities depends not only on the teachers in leading position, but also on the students' awareness of the importance of the curriculum, the original basic knowledge and foreign languages level, and so on.

Teaching environment refers to peripheral factors such as a hardware environment, policy environment, the academic atmosphere etc. which have influence of teaching activities.

\section{The Exploration and Research on Bilingual education of Computer Curriculum}

\section{A. Teaching Goals}

Bilingual education goals include imparting academic knowledge and cultivating students' ability to use foreign language. Among them, the language ability is the foundation of learning discipline. However, Bilingual education should focus on imparting academic knowledge instead of teaching foreign language. Improving our English application abilities is subtly a process of bilingual education, and we can ultimately achieve the win-win situation between mastering the professional knowledge as well as improving the English application abilities [2]. If we misunderstand the teaching goal, bilingual education changes into language teaching, discipline teaching distorts for foreign language teaching.

\section{B. Curriculum Planning}

Computer discipline has the necessity and feasibility to carry out bilingual education. First of all, since the historical origin of computer discipline, regardless of the operating system or advanced programming languages in this field, many advanced theory of technologies and application of products are derived from western English-speaking countries. Although in recent years our country has made great progress of computer technology, but compared with foreign countries we still have a large gap. Therefore, carrying out bilingual education of computer discipline has benefit to raise students' ability to access foreign language documents. In addition, computer discipline has stronger international commonality. In various countries of the world, the expressions of technical jargon, understanding and interpretation of meaning are more consistent. Therefore, the implementation of bilingual education in computer discipline has a good basis in reality.

But at this stage, some computer specialized courses are not appropriate for bilingual education. We select the curriculum of bilingual education very seriously. We do think: many specialized fundamental courses, their difficulty is taller, Moreover, these courses are the foundation of several following-up courses, if imparting instruction is ineffective, it will directly affect the study of other courses. Thus, we should first elect the specialized courses which have less difficulty theory, stronger practical nature, stable professional vocabulary, proper textbooks and rich teaching resources for bilingual education. Here we choose the advanced language programming. Meanwhile, in order to guarantee bilingual education quality, we suggest that we are sough to abolish professional English classes and increase bilingual education hours.

\section{Teachers Training}

Qualified bilingual teachers not only have a solid background in knowledge of computer business, but also have higher level of application in English [1]. However, now the shortage of qualified teachers is the biggest bottleneck to promote the bilingual education in colleges and universities. In view of the above situation, we should adopt the following approaches to improve bilingual teachers' quantity and quality. 
1) College cultivating. In undergraduate teaching stage, encourage the English major students to choose non-English subject as their minor courses, non-English majored students choose foreign language as their minor courses. At the graduate education stage, there are plans to recruit English major students in normal colleges for key cultivating. In addition, we can cooperate in running education with foreign well-known universities, and take the implementation of flexible training mode to comprehensively promote the student's professional knowledge and foreign language proficiency, so that steady stream of graduates will join in the bilingual teachers' team.

2) High-level personnel exchanges. On the one hand, we should select those outstanding teachers in higher academic level to study abroad, in learning the knowledge frontier of our discipline, at the same time, rapidly improve foreign language proficiency; On the other hand, we can actively introduce and bring in foreign teachers with overseas background or high-level academic talents.

3) Perfect talent selection mechanism. In the first place, the policy should be issued to encourage schools to carry out bilingual education, they should incline to the bilingual teachers in teaching allowance, post allowance, positional title assessment in order to improve the attractiveness of bilingual teachers' positions; Secondly, the active subject of bilingual education should be carried out for the teachers' training, increase the teachers' opportunities to participate in training at home and abroad; Finally, the evaluation system of bilingual education should be perfect, bilingual teacher positions enrollment system are strictly enforced, and the implementation of a nationwide system of international bilingual education qualification credentials can be taken.

\section{Students Problem}

In the process of bilingual education in universities, the proficiency of students' foreign language basis will directly affect its consequent. As the students are in different levels of English, the acceptance of bilingual education also vary from person to person. Therefore, it's not appropriate to adopt "one size fits all" solution in bilingual education. For the above situation, our school pays attention to teaching students according to their aptitude in bilingual education practice, models on the ability triage system of Singapore and implements graded teaching. First of all, according to the scores of English baseline test for the undergraduate students after admission, in combination of first-year listening and speaking performance in college, we priority allow to carry out bilingual education in students with better English foundation. Through the small class teaching we accumulate teaching experience and set up the learning typical, so that most students get the good effect of bilingual education to improve their interest in bilingual learning. Meanwhile, in order to adapt to the need of bilingual education, it's necessary to strengthen speaking and listening training in public foreign language teaching.

\section{E. Teaching Material Construction}

Teaching materials are the physical basis and necessary condition in developing teaching, and bilingual materials choices are also an important factor to affect the quality of teaching. In view of the academic frontiers and application software of computer courses are all from western English-speaking countries, at present, the colleges taking bilingual education mostly use the original foreign language textbooks. On the one hand, original foreign language textbooks mostly write by experienced teachers. These textbooks focus on practice, reflect the frontier of the discipline, contents detailed and language authentic. On the other hand, the common characteristic is that the foreign textbooks are having more content, and a big gap with our current teaching syllabuses and courses scheduling in our country. Moreover, due to copyright factors, original textbooks' price is a little higher above the students' bearing ability. It even appears an embarrass phenomenon that teachers order teaching materials, but students are all refuse to buy them when school starts.

Therefore, when choosing teaching materials, we should not only consider the subject development and the need of teaching content, but also consider students' foreign language proficiency and economic conditions. We 
should not blindly pursue high level and difficult materials. When we select materials, in line with meeting the require of theory knowledge of "Delphi Advanced Programming Technology", meanwhile taking the teaching methods of this course and the depth and coherence of the discipline itself into account, we finally choose the excellent original textbook of foreign information discipline named "Mastering Delphi 7". At the same time when we prepare for lessons, we write the internal "concise loose-leaf materials" on the basis of referring to a large amount of related literatures. This textbook focus a number of advantages of materials, at the same time, it rearranges the contents according to the student accept ability. It has an auxiliary explain of some concept and difficult content which Chinese students are easy to be confused. These kind of teaching materials have more refining content, lower price and can be in line with the needs of Chinese students.

\section{F. Education Methods}

\section{1) Teaching Methods}

The way of bilingual courses teaching can be roughly divided into three levels. The first level is given priority to Chinese teaching and matched with English writing on the blackboard. The second level is pay attention to both Chinese and English teaching. The third level is mainly teaching in English and Chinese instructions supplement. Due to the teachers' team and the students' level are both in the primary stage, in line with the principle "from surface to deepness, progressive approach", the author uses the combination of English writings on blackboard, courseware, original textbooks and brief loose-leaf textbooks, from easy to difficult, gradually from the Chinese teaching to transit to English teaching for part of sections. In the class teaching spot, we will give a lecture composed of flexible and diverse teaching forms, create active classroom atmosphere, and cultivate the students' learning interests and comprehensive ability. Second, since computer course is a strong practical course, so more than half of the courses time will be scheduled in the computer room. Till the end of the course, there will be an arrangement of course design for two weeks which make students accomplish a large-scale programming task in English, improving the skills of using professional knowledge.

\section{2) Students Assessment}

Bilingual courses evaluate students through four ways, including:

a) The final exam. Use entire foreign language questions with closed book and the free answer way in Chinese or English. Taking into account the gap between English and mother tongue, these questions will be much easier than those in the Chinese paper of the same course. Adopting full foreign topic can avoid some students only to read Chinese tutorial materials instead of original textbooks.

b) Translate professional literature. The teachers will choose the latest English materials related to the courses, each student will be asked to translate different part of the content, ensuring they complete it independently.

c) To operate on computer. Teachers give out English experiment guidance and goal to achieve, then score according to the students' operating condition.

d) Homework. Feature of the after-school exercises in textbooks and request students to answer in English.

Along with the development of the demonstration course construction, in the future we will gradually develop the computer exam system by English, and perfect examination library, and eventually execute the implementation of computer test in English.

\section{G. Assessment and Evaluation System of Teaching Quality}

The assessment and evaluation system of teaching quality is an important mean to assess the bilingual education quality. It has played a direction and promoted role in the development of bilingual education in 
universities. According to the undergraduate assessment document of nation's Ministry of Education, combined with the actual situation of our school, we take with the scientific, objective and operational as guiding principles, and especially establish a bilingual education quality assessment team. We also refer to the existing achievement in this field both at home and abroad; make use of the classic propagation theory of Lasswell and Bukdorry to construct six primary indexes to the universities' bilingual education quality evaluation which include: teachers' attainment, teaching content, teaching methods, teaching objectives, teaching objects, teaching environment. After the first stage index has been determined, we should repeatedly seek for expert advice through the Delphi method, eliminate the secondary and nonessential evaluation indicators and select the important ones, and then establish the secondary indexes of the bilingual education quality evaluation of universities.

After three years' experience for bilingual education, we designed the evaluation form for experts, teachers and students. Each time before the course starts, during the course process and at the end of it, we do questionnaire through "evaluation form" to teaching supervisors, learning teachers and students. We understand the feedback information from each side of the bilingual education, so as to adjust teaching content and methods in time. Meanwhile considering the characteristics of bilingual education, we increase the proportion of professional English teachers for listening.

\section{H. The Microscopic Policies and Management Mechanism (Teaching Environment)}

1) Establish the incentive mechanism for bilingual education. Because bilingual teachers have planned to invest a lot of time and effort in preparing the courses, it should be an inclination for bilingual education in workload identified and positional title assess. While the teachers who have published English paper in international journals should be rewarded by their influential factors.

2) Establish the bilingual teachers' cultivation mechanism. Through the China Scholarship Council and west talent cultivation plan in China, we can fund the potential backbone teachers of bilingual to study and train abroad. And regularly organize the bilingual teachers to observe and learn excellent national bilingual demonstration curriculum construction projects from brother institutions for communicating teaching experience and lecture skills.

3) Increase the expense and facilities guarantee of bilingual education. They construct of the teacherstudent interaction class for small-class teaching, add interactive electronic whiteboard, and perfect the computer networking exam system and item bank.

4) Establish bilingual education construction and management committee, and formulate related policies of it in order to be responsible for the planning, audit and evaluation of bilingual programs.

\section{Conclusion}

After three years of practice in the teaching reform which has achieved some target, the students' English reading level has been significantly improved, and they have been qualified with the basic skills to read foreign literature, and are able to use application software in English environment fluently. And in 2008, the "Delphi Advanced Programming Techniques" was classified as a national demonstration course of bilingual education project. However, we also aware that there are still many shortcomings in teaching environment, teachers team etc. We hope the whole society take the outlook of scientific development as guidance, fully implement the engineering of undergraduate teaching quality, discard the thinking of one-side pursuit of bilingual education shape and curriculum number in metaphysical form, but deepen the connotation construction of bilingual education, and cultivate more and more high-quality internationalized talents.

\section{References}

[1] M. Young, Bilingual education in China: practices, policies, and concepts. Multilingual Matters, 2007. 
[2] Chen Ning, Undergraduate bilingual education institute of financial review and prospects, Journal of Nanchang College of Education, vol. 25 no. 4. pp:35-39.2010 (in Chinese).

[3] li.Xuan, Comparative study of bilingual education models, Master 's Thesis of Southeast University. China, 2006(in Chinese).

[4] Guangwei Hu. The misleading academic discourse on chinese-english bilingual education in China. Review of educational research. vol. 78 no. 2. pp:195-231.June 2008(in Chinese). 